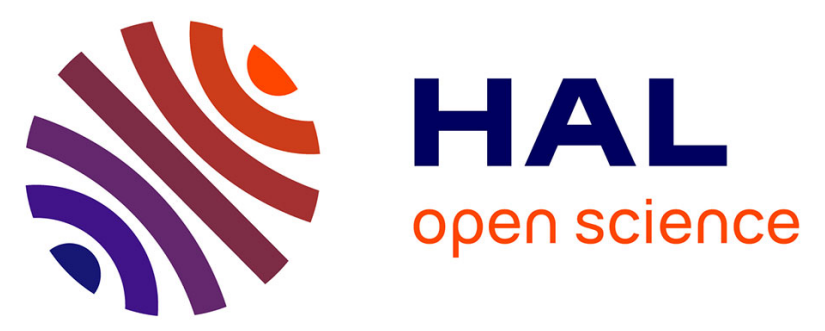

\title{
Konrad Lange on "the Illusion of Materials" in Painting and Visual Arts: Revisiting a Psychoaesthetic Theory of the Perception of Material Properties
}

\author{
David Romand
}

\section{- To cite this version:}

David Romand. Konrad Lange on "the Illusion of Materials" in Painting and Visual Arts: Revisiting a Psychoaesthetic Theory of the Perception of Material Properties. Art and Perception, 2020, 10.1163/22134913-20191126 . hal-03219348

\author{
HAL Id: hal-03219348 \\ https://hal.science/hal-03219348
}

Submitted on 6 May 2021

HAL is a multi-disciplinary open access archive for the deposit and dissemination of scientific research documents, whether they are published or not. The documents may come from teaching and research institutions in France or abroad, or from public or private research centers.
L'archive ouverte pluridisciplinaire HAL, est destinée au dépôt et à la diffusion de documents scientifiques de niveau recherche, publiés ou non, émanant des établissements d'enseignement et de recherche français ou étrangers, des laboratoires publics ou privés. 
Konrad Lange on 'the Illusion of Materials' in Painting and Visual Arts:

Revisiting a Psychoaesthetic Theory of the Perception of Material Properties

David Romand, Ph.D.

\author{
Centre Gilles Gaston Granger \\ UMR 7303 - Aix-Marseille University \\ Maison de la Recherche \\ 29, rue Robert Schuman \\ F-13621 Aix-en-Provence - France \\ Email: david_romand@hotmail.fr
}

Published in

Art and Perception. An International Journal of Art and Perception Science, special issue: The skin of things: On the perception and depiction of materials (edited by J. Stumpel \& M. Wijntjes), 7(3-4), 283-298. 


\begin{abstract}
In the present article, I discuss the concept of 'the illusion of materials' (die Stoffillusion) as it was elaborated in the late 19th and early 20th centuries by the German aesthetician and art historian Konrad Lange (1855-1921). Here I intend to revisit a remarkable theory of the psychological mechanisms that underlie the aesthetic experience of mimesis in painting and, more generally speaking, in visual arts. First, I deal with the historical background of Lange's contribution by saying a word about the German-speaking psychoaesthetic paradigm as it developed between the mid-19th century and WWI. Second, I discuss the basic tenets of Lange's 'illusionistic aesthetics' (Illusionsästhetik), the view according to which the experience of the beautiful lies in a process of 'conscious self-delusion' (bewußte Selbsttäuschung) by which means the contemplating subject mentally oscillates between 'semblance' and 'reality'. Third, I analyze Lange's theoretical way of conceiving the illusion of materials by showing that he identified it as one of the seven chief categories of aesthetic illusions and by insisting on his distinction between the 'subjective' nonaesthetic illusion and the 'objective' aesthetic illusion of materials. Fourth, I show how Lange conceived the place of the illusion of materials in aesthetic experience in general and in the contemplation of painting and sculpture in particular. In a fifth, concluding part, I deal with the significance of Lange's ideas on the illusion of materials today by highlighting their close relation to Daniel Arasse's conception of painting contemplation as a dialectics of 'the pictorial' and 'the iconic', while also suggesting that they may be very fruitful within the context of current experimental psycho- and neuroaesthetic research.
\end{abstract}

\title{
Keywords
}

Konrad Lange; rendering of materials; illusion; illusionism; aesthetics; psychology; painting; visual arts 


\section{Introduction}

The art of rendering materials lies in the artist's skill to more or less accurately reproduce the optical (and eventually tactile) physical properties that characterize the surface of natural objects or artifacts (glossiness, glow, transparency, textures, etc.) by means of concrete materials such as pigments that, as a rule, have nothing to do with the materials to be depicted per se. Here we are dealing with a crucial aspect of the mimetic power of images that has been traditionally attached to visual arts in general, and painting in particular, since the early 15 th century. As a way of reconstituting the perceptual quintessence of objects, the rendering of materials ensures, at least as much as the rendering of space, the verisimilitude of the artistic representation. From the experiential point of view, it is a make-believe process par excellence: by depicting light effects or textures, the artist induces the viewer to perceive the material qualities of the artwork, not as they physically exist in front of him or her, but as they are supposed to be in the corresponding depicted object, and so to spontaneously apprehend the rendered properties as if they were real. Nevertheless, the depiction of materials no more aims to simply delude the contemplating subject than does the gist of visual arts consist in merely mimicking nature. It is a well-known fact that the art of painting consists not only in approaching mimetic effects, but also in intentionally departing from them, such as when the painter uses so-called material effects (impasto, visible brushstrokes) or leaves the linen visible under the paint layer. During the process of contemplation, by alternately embracing the artwork as a whole and focusing on its constitutive details, or by moving back and forth relative to it, the subject typically apprehends materials in either their depictive or their nondepictive dimension, that is, either as being the image of something or as physically belonging to the artwork. Even when perceiving the most mimetically depicted material qualities, the subject remains aware of the fact that he or she is experiencing something fictitious and not real and that artistic depiction is only an approximate way of rendering reality. In this respect, there are good reasons for thinking that the aesthetic impression made by the rendering of materials originates, not from the mimesis per se, but rather from the capacity to appraise its fictitiousness and the discrepancy that exists between what is mimicked and the way of mimicking it. This is the question that $\mathrm{I}$ intend to address in the present article by analyzing the seminal contribution of the German aesthetician and art historian Konrad Lange (1855-1921) (Box 1), who, in the late 19th and early 20th centuries, proposed, within the framework of his 'illusionistic aesthetics', a remarkable theory of the rendering of materials in painting and, more generally speaking, in visual arts. In his magnum opus, Das Wesen der Kunst. Grundzüge einer illusionistischer Kunstlehre [The Nature of Art. Outlines of an Illusionistic Theory of Art] (Lange, 1907), Lange devotes many pages to what he called the illusion of materials, that is, the conscious self-deceiving process by which the viewer 
believes in the existence of the materials depicted without forgetting their artefactual character aesthetic contemplation basically consisting, according to Lange, in the fact of mentally oscillating between 'semblance' and 'reality' and in the resulting experience of harmoniously switching from one perceptual mode to the other. Here I aim to discuss the ins and outs of Lange's psychoaesthetic model of the rendering of materials by placing it within its historical context and within the context of the illusionistic aesthetics, while insisting on its theoretical significance in light of current aesthetic research.

\section{Historical Background: German-Speaking Psychological Aesthetics in the Late 19th and early 20th Centuries}

Although, as the subtitle indicates, the second edition of Das Wesen der Kunst is supposed to be devoted to 'theory of art', and not to aesthetics properly speaking (Lange, 1907, p. 1), the theoretical developments proposed in it by Lange are directly in keeping with aesthetic concerns. As he reminds us, aesthetics "is a psychological science, a part of psychology", because "it has to do with the description of a human psychical state" ${ }^{1}$ (Lange, 1907, p. 15). Nevertheless, Lange, who admitted to not being an expert in psychology (Lange, 1907, p. 16), did not try to discuss at length the psychological foundations of aesthetics. According to him, aesthetics the latter is closely related, not only to psychology, but also to art history, a discipline that, in his view, is likely to provide evidence (Beweismaterial) to the aesthetician (Lange, 1907, pp. 14-37)2.

In the 1850s-1860s, a 'psychological turn' characteristically affected German and Austrian aesthetics (Allesch, 1987; Romand, 2018). Psychology, as it had been elaborated by German scholars since the early 19th century, became a major source of inspiration for aestheticians, who took up its main concepts, its theoretical models, its methods, as well as, more generally speaking, its epistemological interpretative framework (Romand, 2018). For more than half a century, namely, until WWI, psychological aesthetics established itself as the leading paradigm of aesthetic research (Allesch, 1987; Romand, 2018). According to the view that was then prevailing in Germanspeaking countries, the aesthetician's task is to study the artwork in its relation to the contemplating subject, that is, to deal with the aesthetic object as it is effectively experienced in consciousness, disregarding what it is supposed to consist of in the external world. More specifically, psychological aesthetics, as conceived by Lange and his contemporaries, had basically to do with how the aesthetic object (der ästhetische Objekt), by being apprehended by the subject, is likely to produce a

1 All translations from German and French are mine.

2 In fact, Lange's contribution to aesthetics proves to be theoretically less sophisticated butand also less abstract than that of most of his contemporaries (e.g. Lipps, 1903-1906; Volkelt, 1905-1910-1914). Despite these idiosyncrasies, the fact remains that Lange can be regarded as a good representative of the psychoaesthetic paradigm that prevailed in German-speaking countries in the late 19th and early 20th centuries. 
definite effect (Wirkung) on him or her and to be appraised as beautiful (or ugly). Here we are dealing with a mentalistic research program, according to which all aesthetic properties should be interpreted on the basis of two main categories of mental states: representations (Vorstellungen), the entities of a sensory nature that constitute the content of conscious experience, and feelings (Gefühle), the subjective factors that permit one to evaluate the contents of consciousness (Romand, 2018). In fact, feeling is the core concept of the German-speaking psychological aesthetics, the aim being, first and foremost, to understand the subject's evaluative capacity of the aesthetic object (Romand, 2015). Like the other psychoaesthetic models of that time, Lange's aesthetics has basically to do with the issue of aesthetic feelings (ästhetische Gefühle) (Romand, 2015, 2018).

\section{The Basic Tenets of Lange's Illusionistic Aesthetics}

\subsection{Lange and the Illusionistic Tradition in Aesthetics}

Lange was the major exponent of what he himself called the illusionistic aesthetics (die Illusionsästhetik) (Lange, 1895, 1906, 1907, 1919). By 'illusionistic aesthetics', he referred to the theory according to which one's capacity to appraise an aesthetic object basically results from the manifestation of an illusion (Illusion) or a semblance (Schein), that is, from the fact of experiencing it as something other than what it is in reality. More specifically, for Lange, aesthetic enjoyment consists of being consciously self-deceived by the artwork. In other words, he identified aesthetic contemplation with a process of conscious self-deception (bewusste Selbsttäuschung) (Lange, 1895, 1907). Aesthetic illusion, Lange insists, differs from ordinary illusory phenomena in that, in such a case, we freely accept being illuded, while remaining aware of the fact that what we are experiencing is not real but only apparent. As he explains, when contemplating an artwork, our sensory perception of it is the substrate from which "we construe, by means of imagination, an image of reality" (Lange, 1907, p. 63). This image becomes the surrogate of a thing, an individual, or an action that is not actually present but that we are acquainted with. It is worth noting that, for Lange, the phenomenon of conscious self-delusion is not restricted to imitative arts, but corresponds to a universal aesthetic principle that plays a role in non-imitative arts as well (Lange, 1907) ${ }^{3}$.

First expounded in the 1895 essay Die bewußte Selbsttäuchung als Kern des ästhetischen Genusses [Conscious Self-Delusion as the Core of Aesthetic Enjoyment] (Lange, 1895), Lange's views on aesthetic illusionism found their mature expression in Das Wesen der Kunst, a book

3 Regarding the so-called non-imitative arts, aesthetic illusion originates, not from "an accurate imitation, but [from] a rough approximation of the model" (Lange, 1907, p. 106). This is typically the case for musical aesthetics, which, in Lange's view, consists of mimicking phenomena of an impersonal and undetermined nature, such as natural sounds, motion, or states of mind. 
published in 1901 and in 1907 in a revised and expanded edition (Lange, 1907). The epitome of illusionistic aesthetics in the late 19th and early 20th centuries, Lange was by no means the founder of this aesthetic current. By his own admission (Lange, 1906), illusionism is an old issue of the German aesthetic tradition, whose origins can be traced back to the late 18 th century ${ }^{4}$.

\subsection{Aesthetic Illusion and Feelings}

As defined by Lange, the phenomenon of conscious self-deception has to do, in the final analysis, with feelings (Gefühle), which constitute the immediate source of aesthetic enjoyment (ästhetischer Genuß). As he explains in his 1895 essay (Lange, 1895), the fact of being illuded by the contemplated artwork should be ascribed to a definite kind of affective state, the feeling of semblance (Scheingefühl). The fact of experiencing it as something real, by contrast, should be ascribed to what he calls the feeling for reality (Gefühl für Wirklichkeit).

Nevertheless, Lange insists that the manifestation of the feeling of semblance alone is not responsible for aesthetic enjoyment. In fact, aesthetic enjoyment relates, not to semblance or illusion per se, but rather to our capacity to mentally switch from an illusory to a non-illusory state and vice versa. According to Lange, this 'psychological experience of change' between semblance and reality is the very source of aesthetic pleasure. More specifically, as he emphasizes in Das Wesen der Kunst, the aesthetic effect of the artwork ultimately originates from 'the feeling of freedom' (das Gefühl der Freiheit) or 'the feeling of mental freedom' (das Gefühl der geistlichen Freiheit) (Lange, 1907, pp. 296-297) that, in the process of conscious self-delusion, gives us the impression of 'rising above the realities of life' (Lange, 1907, p. 296) and 'freely floating above things' (Lange, 1907, p. 297).

\subsection{Aesthetic Experience as a Conscious Back and Forth between Two Series of Representations}

The idea of a switch between deception and non-deception is at the heart of Lange's

4 As Lange emphasized, in the wake of Moses Mendelssohn's seminal studies (Mendelssohn, 1972), aesthetic illusionism was theorized by prominent scholars such as Kant (2000/1790) and Schiller (1967/1795), who both insisted on the role of semblance (Schein) and play (Spiel) in the experience of the beautiful. In the late 19th century, the illusionistic stance was revived and formalized by Eduard von Hartmann within the context of psychological aesthetics (Hartmann, 1887). Hartmann interpreted aesthetic illusion as the manifestation of a "feeling of semblance" (Scheingefühl), an expression and a concept that would be taken up by Lange. Although Lange makes no mention of Hartmann in his writings, Hartmann should be regarded as his direct predecessor and, presumably, as one of his major sources of inspiration. On the other hand, Lange's developments on aesthetic illusion and conscious self-delusion are reminiscent of a number of other contemporary psychoaesthetic models. Here what comes to mind is Karl Groos's conception of aesthetic enjoyment as play and inner imitation (innere Nachahmung) (Groos, 1902) and Theodor Lipps's theory of aesthetic empathy (ästhetische Einfühlung) (Lipps, 1903-1906). These two authors agree with Lange that contemplating the artwork basically consists in experiencing it as something fictitious, detached from ordinary reality. 
illusionistic theory. In Das Wesen der Kunst, Lange provides clarifications about the psychological processes at stake in this switching movement. As he explains, when contemplating an aesthetic object, our "consciousness oscillates back and forth between the belief in reality and the knowledge of non-reality" (Lange, 1907, p. 264). Here we are dealing with two 'series of representations' (Vorstellungsreihen), that is, two kinds of contents of consciousness - each being accompanied by definite feelings - that correspond to the aesthetic object experienced in its material concreteness and as an image (Lange, 1907, pp. 272-298). Lange also speaks of the series of representations 'art' (Kunst) and the series of representations 'nature' (Natur). As he highlights, these two series compete with each other for access to the focus of consciousness (Blickpunkt des Bewusstseins) ${ }^{5}$, so that each of them alternately ends up in it. While one series of representations is in the focus of consciousness, the other one remains confusedly conscious outside of it (Lange, 1907, pp. 272-276).

Nevertheless, Lange insists, it would be misleading to assume that the two series as a whole alternately come into consciousness and draw back from it. In fact, rather than from a whole series of representations to another, the contemplating subject switches between their constitutive elements, so that he or she is able to experience, in turn, the same parts of an artwork as real or fictitious (Lange, 1907, pp. 275-276). Whether experiencing reality or semblance, he or she is always aware of the connection between the two series and can decide at all times to turn back to the opposite conscious state. That is why, according to Lange, aesthetic contemplation as a whole appears as a homogeneous experience (Lange, 1907, p. 263).

\subsection{Illusion-Arousing and Illusion-Disrupting Elements}

On the basis of the previous developments, it is clear that "both kinds of series are necessary for aesthetic enjoyment" (Lange, 1907, p. 279). The fact that, at some point, one or the other is apprehended in consciousness depends on two kinds of properties inherent to the aesthetic object, namely, the illusion-arousing and the illusion-disrupting elements (die illusionserregenden/illusionsstörenden Elemente), which, as the names indicate, tend to enhance and to reduce the contemplating subject's deceptive experience, respectively (Lange, 1907, pp. 220245).

As a rule, the illusion-arousing elements consist of all artistic means that are in line with the

5 Although Lange does not mention his name, "the focus of consciousness" (der Blickpunkt des Bewusstseins) is a transparent reference to Wilhelm Wundt, who, in the late 19th century, had coined the expression and developed the corresponding psychological concept within the framework of his theory of apperception. As Wundt explained (e.g. Wundt, 1903, pp. 333-337), representations (Vorstellungen) that occur at a given moment in the field of consciousness (der Blickfeld des Bewutsseins) enter the focus of consciousness (der Blickpunkt des Bewußtseins) as soon as attention is directed to them and raises them from the level of perception (Perzeption) to the consciously clearer level of apperception (Apperzeption). 
imitation of nature, that is, for instance:

"The anatomical, botanical, or geological correctness of the contours, the chiaroscuro as a means of [representing] space three-dimensionally on the surface, perspective as the art of spatial deepening, the correspondence of motions, facial expression, coloring, voice, etc. with nature, the psychologically true expression of thought and feelings (...)." (Lange, 1907, p. 222)

In Das Wesen der Kunst, Lange devotes a whole chapter to the issue of illusion-disrupting elements (Lange, 1907, pp. 220-245) by insisting on those involved in the contemplation of visual arts. The frame, flatness (Flächenhaftigkeit), and immobility, on the one hand, and the pedestal, the physical nature of materials, and immobility, on the other hand, are, in his view, the chief categories of illusion-disrupting elements that are characteristic of painting and sculpture, respectively. As Lange emphasizes, although he or she strives to overcome them, the contemplating subject is never able to ignore the illusion-disrupting elements, whatever they may be. The fact is that they "are by no means superfluous and an obstacle to aesthetic enjoyment" (Lange, 1907, p. 220) - quite the contrary. According to Lange, indeed, "in addition to being a prerequisite of it, the conscious perception of (...) illusion disrupting elements is an integral part of aesthetic enjoyment" (Lange, 1907, p. 247). Their aesthetic function lies not only in the fact of being a condition of the switching movement inherent to the self-conscious delusion, but also in the possibility of being identified and recognized as such (Lange, 1907, p. 247). Hence, when contemplating an artwork, the subject is supposed to understand that "the artist's intention [was] clearly [to] make [him or her] conscious of the illusion disrupting elements" (Lange, 1907, p. 232).

More generally speaking, both categories of elements must give the impression of reflecting a definite artistic personality (Lange, 1907, pp. 264-265). As Lange explains, "the contemplating subject must have the feeling that a sagacious artistic mind created the illusion arousing as well as the illusion disrupting elements, arranged them and put them in relation in order to produce the effect that we experience when perceiving the artwork" (Lange, 1907, p. 265).

\section{The Psychological Foundations of the Aesthetic Illusion of Materials}

\subsection{Illusion of Materials as a Definite Category of Aesthetic Illusion}

As Lange highlights in Das Wesen der Kunst, "as nature or life has an endless number of properties, so, to be precise, there is also [in art] an endless number of illusions" (Lange, 1907, p. 
91). Nevertheless, he focuses on seven main categories of aesthetic illusions that, according to him, are characteristically (but not exclusively) encountered in the visual arts that includes painting, sculpture, architecture, and arts and crafts (Lange, 1907, pp. 74-102). Here we are dealing with the illusion of materials, the spatial illusion, the illusion of motion, the illusion of light, the illusion of color, temporal illusion, and the illusion of action. These seven illusions manifest themselves with more or less strength in the various art forms, as shown in Table 1. They take part in the process of contemplation of the artwork and, by interacting with each other, contribute to the emergence of the global aesthetic effect produced by the artwork.

Lange defines the illusion of materials (Stoffillusion) in simple terms as the illusion that occurs when materials "of which an object consists are depicted by other materials that only mimic real materials (...)" (Lange, 1907, p. 74). For him, unsurprisingly, this kind of aesthetic illusion is encountered first and foremost in painting, in which, along with space and motion illusion, it plays a major role (Table 1). More specifically, the painterly illusion of materials "consists in the fact of having a representation (wir uns... vorstellen) of the materials of an object depicted by painting when we look at the pigments by which means the latter is depicted" (Lange, 1907, p. 75). Here we are dealing with an illusory phenomenon because we experience a 'semblance' of materials instead of the 'real' matters that physically constitute the artwork. Notably, Lange insists on the fact that in painting, colors and combinations of colors "have no independent meaning, but are at the service of the illusion of materials" (Lange, 1907, p. 545). Hence, according to him, there is no painterly illusion of color per se and, in any case, the illusion of materials is also involved, although in a limited way, in a number of other imitative arts, namely, graphic arts, sculpture, performing arts, and poetry (Table 1).

\subsection{Subjective vs. Objective Illusion of Materials}

The core of Lange's developments on the aesthetic illusion of materials is that it is not a 'subjective' but an 'objective' illusion (Lange, 1907, pp. 93-96).

What he referred to as a subjective illusion "consists in the fact that we imagine ourselves being in a situation in which we identify with a thing or an individual, that we believe that we do or experience something that we neither do nor experience in reality" (Lange, 1907, p 92-93). Hence, the illusion of material is said to be subjective when "we have the impression of touching (anfühlen) the materials that we see" (Lange, 1907, p. 93). Here, as Lange highlighted, we are dealing with an illusion that relates not to the perceived object, but to ourselves, we the viewers. He cites the example of the tactile experience that occurs when we gaze at cloth such as velvet and satin (Lange, 1907, pp. 94-95). In such a case, we effectively have the impression of touching the 
piece of cloth, because, as he explained, we spontaneously associate visual with tactile sensations, two kinds of sensory data that we used to perceive together in the past (Lange, 1907, pp. 93-94). This results in what Lange called a 'subjective tactile illusion' (subjektive Tastillusion).

This subjective tactile illusion is precisely not the type of experience that occurs when we contemplate painted velvet or satin. As Lange emphasized, "in the painterly illusion of materials, we do not feel velvet and satin, but we believe that we really see them in the painted material" (Lange, 1907, p. 119). Our aesthetic appraisal of the rendering of materials has to do not with a subjective but with an objective illusion of materials (objektive Stoffillusion). In that case, rather than reviving tactile sensations and combining them with visual sensations, "we mentally permute two objects that exist outside of us: one that belongs to art and one that belongs to the realm of nature, one that effectively exists and one that exists only in thought" (Lange, 1907, p. 92). The fact that tactile sensations, and, more generally speaking, the subjective illusion of materials, are not involved in aesthetic experience is not specific to the painterly rendering of cloth, but concerns the rendering of all kinds of materials, whatever the art form may be. As Lange emphasized, when contemplating painted strawberries or 'Dutch breakfast paintings', we are not supposed to foam at the mouth or to experience gustative sensations (Lange, 1907, pp. 155-156). The subjective illusion of materials, Lange insists, is devoid of aesthetic value. Its manifestation when one views an artwork is a coarse and basic way of enjoying art, typical of uneducated people (Lange, 1907, p. 94) ${ }^{6}$.

\section{The Place of the Illusion of Materials in Aesthetic Experience}

\subsection{The Aesthetic Function of the Illusion of Materials}

Although it is supposed to be crucial only for painting (Table 1), the issue of the objective illusion of material turns out to be a favored field of investigation of Lange's aesthetics in general. The experience of the rendering of material properties is at the heart of his developments on how aesthetic enjoyment results from our power of mentally switching between semblance and reality. In Das Wesen der Kunst, Lange gives us many examples of the way in which our "double apprehension" of materials occurs and may decisively contribute to our capacity to be consciously self-deluded by the artwork. According to him, indeed, "among all aesthetic illusions, the illusion of

6 In Das Wesen der Kunst, Lange also mentions a special form of subjective illusion that was commonly said to be instrumental for aesthetic contemplation. More specifically, he criticized the view, advocated by contemporary aestheticians, that the rendering of materials would consist in "immers[ing] oneself in the materials, as if", for instance, "one would be oneself velvet or satin, one would crease oneself the satin garment that touches the ground and one would oneself hug with velvet the forms of the body" (Lange, 1907, p. 96) - a view that seems abstruse to him. Here Lange explicitly stands against the then very popular theory of aesthetic empathy (ästhetische Einfühlung), of which Lipps (1903-1906) was the chief exponent. 
materials is the most tangible, the most understandable one, the one that lies most on the surface" (Lange, 1907a, p. 76). Moreover, in the case of painting, he "consider[s] the image's illusion of materials, irrespective of perhaps higher qualities, as the prerequisite for aesthetic enjoyment or the first step toward it" (Lange, 1907, p. 76).

In any case, as addressed by Lange, the issue of the aesthetic experience of materials puts a clear focus on the complementary roles played by illusion-arousing and illusion-disrupting elements in the process of contemplation. As stated earlier, when contemplating an aesthetic object, we should take into account both categories of elements, while being aware of the fact that they have been purposely used by the artist. Hence, Lange insists, in order to make an aesthetic effect, the artwork should meet, as a rule, two criteria: (a) It should not be too naturalistic, but, on the contrary, should give us the impression of being a more or less approximate rendering of reality; and (b) it should appear to us as the result of a compromise between what the artist has intended to represent and the physical constraints of the material that it is made of (Lange, 1907, pp. 299-341). In either case, the perception of material properties is particularly suited to the study of how illusionarousing and illusion-disrupting elements are likely to interplay with each other.

\subsection{Illusion of Materials in the Aesthetic Experience of Painting and Sculpture}

Interestingly, Lange's most original developments on the illusion of materials concern sculpture, not painting (Lange, 1907, pp. 303-309). This may seem ironic, since, by his own admission, this kind of aesthetic illusion proves to be much less crucial for sculpture than for painting (Table 1).

Regarding the painterly illusion of materials, he discusses, for instance, our capacity to experience colors, either in their "pure coloristic-decorative relationships" or as local hues, that is, as material constitutive properties of the natural object (Lange, 1907, pp. 278). Moreover, he recurrently insists on how brushstrokes disrupt the illusion of matters and make us perceive the painting both in its physical materiality and in its iconic dimension (Lange, 1907, p. 288). In that case, he shows how, together with other properties, illusory materials 'pop up' in the viewer's consciousness. Lange also proposes interesting developments on how the illusion of matters can be used by the painter as one of several alternatives to aesthetically render, in an abridged way, hardly reproducible natural objects (Lange, 1907, pp. 318-319). Here he takes the example of foliage, which can be rendered by means of either spatial illusion or the illusion of matters, and hair, which can be rendered on the basis of either "[their] linear form and [their] movement" or "[their] material aspect and [their] shine" (Lange, 1907, p. 349).

In the case of sculpture, Lange insists on the fact that the aesthetic perception of materials 
has much to do with the contrast existing between the nature of the illusory materials and the nature of the concrete materials that serve to render them (Lange, 1907, pp. 303-312). As he highlights:

"The bright, white grain of marble, the spotted, polished surface of granite, the metallic reflection of burnished bronze, the dull, plain surface of clay and wood are so many things that contrast so sharply with the soft, porous, translucent, and velvety human flesh, the smooth, silky nature of hair, the either soft and rugged or smooth and crumpled materials of garments that it is impossible to confound them." (Lange, 1907, p. 225)

Just as in painting, the recourse to the illusion of materials in sculpture appeals to simplification and abbreviation (Lange, 1907, p. 304). According to Lange, "it would be pointless for the sculpt[or] to strive to accurately render the texture of the epidermis with [all] its wrinkles, pores, and hairs" (Lange, 1907, p. 305). Rather, "the aesthetic treatment of the epidermis consists (...) in suppressing countless details", as this is the case for "the organic characterisation of the skin, which should be limited to some aspects only, such as to the joints at which it forms wrinkles" (Lange, 1907, p. 306). The same aesthetic principles apply to the rendering of the textures of garments. Here the challenge is, as a rule, "to find a way of treating surfaces that, while producing [an] approximate impression of naturalness, keeps alive the feeling for the typical peculiarities of the material (die charakteristischen Eigentümlichkeiten des Materials)" (Lange, 1907, p. 306).

\section{Conclusion: Today's Significance of Lange's Illusionistic Theory of the Rendering of} Materials

Konrad Lange's developments on the illusionistic aesthetics of painting in general and on the painterly illusion of materials in particular unexpectedly re-emerged in Daniel Arasse's book, Le Détail. Pour une histoire rapprochée de la peinture [The Detail. For a Close-Up History of Painting], first published in 1992 (Arasse, 1996). In chapter 3, entitled 'Paradoxes' (Arasse, 1996, especially pp. 268-289), Arasse proposes a (ever since rather famous) distinction between 'the pictorial' (le pictural) and 'the iconic' (l'iconique), that is, between painterly properties considered in their purely material aspect and in their depictive, mimetic power, respectively. As he emphasizes, both pictorial and iconic details are involved in the contemplation of painting, and the confrontation between the two proves to be a major source of aesthetic enjoyment. Such a conception is strikingly reminiscent of Lange's investigations on conscious self-delusion and the role played by illusionarousing and illusion-disrupting elements. In his book, Arasse gives much space to the question of the perception of material properties by showing how, in that case, the viewer mentally 'switches' 
between reality and semblance. Interestingly, in addition to using the term 'illusion' (illusion), he explicitly speaks of "the consciousness of this oscillation (la conscience de cette oscillation) inherent to the look of a painting" (Arasse, 1996, p. 251). Nevertheless, at no time does Arasse mention Lange, with whom, apparently, he was not acquainted. Moreover, it is worth noting that, unlike Lange, he does not propose any psychological explanation of the psychological processes at stake in the manifestation of the pictorial/iconic dialectics ${ }^{7}$.

On the other hand, one can wonder about the significance of Lange's developments on aesthetic illusion in general and on the illusion of materials in particular in light of current psychoand neuroaesthetic research. The sophisticated psychology-based model expounded in Das Wesen der Kunst can be regarded as a working hypothesis that is likely to be experimentally tested on the basis of modern scientific protocols and techniques. In this respect, it would be interesting to show whether the contemplating subject allocates his or her attention to two series of visual representations; whether he or she experiences definite affective states such as the feeling of semblance, the feeling for reality, and the feeling of mental freedom; whether there exists something like a subjective and an objective illusion of materials; or what the criteria are, inherent to the illusion phenomenon, that make mimesis aesthetically significant. The rendering of materials proves to be particularly appropriate to test Lange's hypothesis that aesthetic experience originates in conscious self-delusion and to identify the presumptive mental and neural processes that underlie its appearance, not only because it has a strong illusionistic power, but above all because materials are likely to be apprehended, much more easily than colors and space, from a double "pictorial" and "iconic" perspective. Hence, the issue of the illusion of materials is likely to become the subject of a fruitful experimental research program, focused on the specifically aesthetic question of how materials are effectively experienced and appraised in consciousness.

\section{Acknowledgments:}

I thank Jeroen Stumpel and Maarten Wijntjes, the organizers of the symposium "The Skin of Things", for having given me the opportunity to deliver a talk about Lange and the illusion of

7 While Arasse's contribution beautifully shows the relevance of Lange's illusionistic aesthetics in light of current art history and theory of art, it also reveals how Lange's ideas fell into oblivion after his death and are still largely forgotten today. Another striking example of Lange's posthumous critical (un)fortune is given by Ernst Gombrich, who, in Art and Illusion, only mentions him en passant and in a rather condescending way: "At the beginning of this century (...), the German critic Konrad Lange wrote a long book on the aesthetics of illusion. He saw, correctly I believe, that all rendering of images demands what Coleridge calls a 'willing suspension of disbelief.' To him all aesthetic pleasure in art was rooted in our oscillation between two series of associations, those of reality and those of art. The terminology and the examples of the book sound curiously old-fashioned, and its aesthetic bias is no longer ours" (Gombrich, 1960, p. 280). Such a snap judgement, which demonstrates a stunning lack of understanding of the German psychoaesthetic tradition, is surprising from a distinguished scholar who has been commonly regarded as having revived, in the second half of the 20th century, the interest in both psychological issues and illusionism in aesthetics and art history. 
materials.

\section{References}

Allesch, C. (1987). Geschichte der psychologischen Ästhetik. Untersuchungen zur historischen Entwicklung eines psychologischen Verständnisses ästhetischer Phänomene. Verlag für Psychologie Hogrefe, Göttingen.

Arasse, D. (1996). Le détail. Pour une histoire rapprochée la peinture. Flammarion, Paris.

Eisler, R. (1912). Lange, Konrad, in: Philosophen-Lexikon. Leben, Werke und Lehren der Denker, R. Eisler (Ed.), pp. 383-384, Mittler, Berlin.

Gombrich, E. (1960). Art and Illusion. A Study in the Psychology of Pictorial Representation, Princeton University Press, Princeton.

Groos, K. (1902). Der aesthetische Genuss, Ricker, Giessen.

Hartmann, E. von (1887). Ästhetik, Zweiter systematischer Teil: Philosophie des Schönen, Haacke, Leipzig.

Kant, I. (2000). Critique of the Power of Judgment, edited by P. Guyer, translated by P. Guyer \& E. Mathews, The Cambridge Edition of the Works of Immanuel Kant, Cambridge University Press Cambridge \& New York. (text first published 1790).

Kjerbüll-Petersen, L. (1921). Zur Erinnerung an Konrad Lange. Zeitschrift für Ästhetik und allgemeine Kunstwissenschaft, 16, 210-216.

Lange, K. (1895). Die bewußte Selbsttäuschung als Kern des künstlerischen Genusses, Veit, Leipzig.

Lange, K. (1906). Die ästhetische Illusion im 18. Jahrhundert. Zeitschrift für Ästhetik und allgemeine Kunstwissenschaft, 1, 30-43.

Lange, K. (1907). Das Wesen der Kunst. Grundzüge einer illusionistischen Kunstlehre, Grote, 
Berlin ( $2^{\text {nd }}$ edition).

Lange, K. (1908). Matthias Grünewalds Stuppacher Madonna. Jahrbuch der Königlich Preussischen Kunstsammlungen, 29, 44-61.

Lange, K. (1919). Die ästhetische Illusion und ihre Kritiker. Annalen der Philosophie, 1, 424-472.

Lange, K. (1920). Das Kino in Gegenwart und Zukunft. Enke, Stuttgart.

Lipps, T. (1903-1906). Ästhetik, Psychologie des Schönen und der Kunst, 2 vol., Voss, Leipzig.

Märker, P. (1982). Lange, Konrad von, in: Neue Deutsche Biographie, vol. 13, pp. 550-551. $<$ https://www.deutsche-biographie.de/pnd116703652.html\#ndbcontent>

Mendelssohn, M. (1972). Schriften zur Philosophie und Ästhetik, in: Gesammelte Schriften Jubiläumsausgabe, vol. 3/1, F. Bamberger \& L. Strauss (Eds.), Frommann-Holzboog, Stuttgart-Bad Cannstatt.

Romand, D. (2015). Theodor Waitz and the rise of affective sciences in the mid-19 ${ }^{\text {th }}$ century. History of Psychology, 18, 385-400. < $\quad$ http://dx.doi.org/10.1037/a0039797>

Romand, D. (2018). Nahlowsky's psychological aesthetics. British Journal of Aesthetics, 58, 17-36. $<$ https://academic.oup.com/bjaesthetics/article-abstract/58/1/17/4838354>

Schiller, F. (1967). On the Aesthetic Education of Man: In a Series of Letters, edited and translated by E. M. Wilkinson \& L. A. Willoughby, Clarendon Press, Oxford (text first published 1795).

Volkelt, J. (1905-1910-1914). System der Ästhetik, 3 vol., Beck, München.

Wundt, W. (1903). Grundzüge der physiologischen Psychologie, vol. 3, Engelmann, Leipzig (5 ${ }^{\text {th }}$ edition). 
Konrad Lange (from 1903 onward von Lange), once ranked among the most famous aestheticians of his time, is nowadays an almost forgotten figure of the German intellectual world (Eisler, 1912; Kjerbüll-Petersen, 1921; Märker, 1982). Born in 1855 in Göttingen, he studied art history and archaeology in various universities, teaching as an associate professor in Göttingen (1884) and Königsberg (1892), before finishing his academic career as a full professor in art history (then in "science of art") in Tübingen a tenure that he held from 1894 onward. Interestingly, by his own admission (Lange, 1907, p. 16), Lange was among the very few theorists of aesthetics of the late 19th and early 20th centuries originating from art history, the vast majority of contemporary "professional aestheticians" being also professional philosophers. As an art historian, Lange was an expert in German Renaissance art. He is still known in some quarters for having decisively contributed to attributing the Stuppach Madonna to Grünewald in a paper issued in 1908 (Lange, 1908). Besides his professorship at the University of Tübingen, Lange was also active in developing museums and schools of art throughout the kingdom of Württemberg. In particular, between 1901 and 1907, he was the head of the Staatsgalerie of Stuttgart, which he modernized significantly. But Lange became famous primarily for his aesthetic research, as expounded in particular in Das Wesen der Kunst [The Nature of Art] (Lange, 1907), a book that ranks among the great aesthetic treatises of the time and that was much discussed by contemporaries. He was an upholder of the so-called illusionistic aesthetics (Illusionsästhetik), also called aesthetic illusionism (ästhetischer Illusionismus), the view according to which the experience of the beautiful basically consists in a conscious self-delusive process during which the contemplating subject mentally oscillates between reality and semblance. Beyond his belonging to the German illusionistic aesthetic tradition, Lange's aesthetic thought should be placed in the context of the prevailing paradigm of psychological aesthetics. Finally, it is also worth mentioning that Lange was an early theorist of cinema. In 1920 he published a thick book, Kino in Gegenwart und Zukunft [Present and Future of Cinema] (Lange, 1920), one of the first systematic studies in the field, in which he harshly criticizes cinema both as an artistic and social practice.

\section{Box 1: Konrad Lange (1855-1921)}




\begin{tabular}{|c|c|c|c|c|c|c|c|}
\hline & $\begin{array}{c}\text { Illusion of materials } \\
\text { (Stoffillusion) }\end{array}$ & $\begin{array}{l}\text { Spatial illusion } \\
\text { (Raumillusion) }\end{array}$ & $\begin{array}{l}\text { Illusion of motion } \\
\text { (Bewegungsillusion) }\end{array}$ & $\begin{array}{l}\text { Illusion of light } \\
\text { (Lichtillusion) }\end{array}$ & $\begin{array}{l}\text { Illusion of color } \\
\text { (Farbenillusion) }\end{array}$ & $\begin{array}{l}\text { Temporal illusion } \\
\text { (Zeitillusion) }\end{array}$ & $\begin{array}{l}\text { Illusion of action } \\
\text { (Handlungsillusion) }\end{array}$ \\
\hline Painting & +++ & +++ & +++ & ++ & + & ++ & ++ \\
\hline Graphic arts & + & +++ & +++ & ++ & +++ & ++ & +++ \\
\hline $\begin{array}{l}\text { Sculpture in the } \\
\text { round }\end{array}$ & + & & +++ & & ++ & + & +++ \\
\hline Relief & + & +++ & +++ & & ++ & + & +++ \\
\hline Performing arts & ++ & +++ & ++ & +++ & & +++ & ++ \\
\hline $\begin{array}{l}\text { Dramatic and epic } \\
\text { poetry }\end{array}$ & + & ++ & ++ & + & + & +++ & +++ \\
\hline
\end{tabular}

Table 1: Degrees of involvement of the chief categories of aesthetic illusions in the various artistic domains (adapted from Lange, 1907, p. 92). 